\title{
Sensitized Photooxygenation of Ent-Pimaradiene Derivatives
}

\author{
Frederico G. Cruz, Martins D. de Cerqueira and Nídia F. Roque \\ Instituto de Química, Universidade Federal da Bahia, Campus Universitário de Ondina, 40170-290 \\ Salvador - BA, Brazil
}

\begin{abstract}
Ésteres metílicos dos diterpenos ácido ent-pimara-9(11),15-dien-19-óico (1), ácido ent-pimara7,15-dien-19-óico (2) e ácido ent-pimara-8,15-dien-19-óico (3) foram submetidos a reações de fotooxigenação via formação sensibilizada de oxigênio singlete. Enquanto os compostos $\mathbf{2}$ e $\mathbf{3}$ foram totalmente convertidos nos produtos, o composto $\mathbf{1}$ reagiu apenas parcialmente sugerindo uma influência do impedimento estéreo sobre a ligação dupla endocíclica deste diterpeno. Os produtos de oxidação obtidos, $7 \alpha, 11 \beta$-diidroxipimara-8,15-dien-19-oato de metila (5), $7 \alpha$-hidroperoxipimara8(14),15-dien-19-oato de metila (6), $7 \alpha$-hidroxi-14-oxopimara-15-en-19-oato de metila (8), $7 \alpha, 9 \alpha$ diidroxipimara-8(14),15-dien-19-oato de metila (9) e $7 \alpha, 14 \alpha$-diidroxipimara-8,15-dien-19-oato de metila (10) são inéditos e suas estruturas foram determinadas pela análise de seus dados espectrais.
\end{abstract}

Methyl esters of diterpenoids ent-pimara-9(11),15-dien-19-oic acid (1), ent-pimara-7,15-dien19-oic acid (2), and ent-pimara-8,15-dien-19-oic acid (3) were submitted to photooxygenation reactions with sensitized singlet oxygen. While compounds $\mathbf{2}$ and $\mathbf{3}$ were converted to the products, compound 1 reacted only partially, suggesting an influence of the steric hindrance on the endocyclic double bond of $\mathbf{1}$. The oxidation products obtained, methyl-7 $\alpha, 11 \beta$-dihydroxypimara-8,15-dien-19oate (5), methyl-7 $\alpha$-hydroperoxypimara-8(14),15-dien-19 oate (6), methyl-7 $\alpha$-hydroxy-14oxopimara-15-en-19-oate (8), methyl-7 $\alpha, 9 \alpha$-dihydroxypimara-8(14),15-dien-19-oate (9) and methyl$7 \alpha, 14 \alpha$-dihydroxypimara-8,15-dien-19-oate (10), are new and their structures were elucidated by spectral data analysis.

Keywords: diterpenes, ent-pimaradiene derivatives, singlet oxygen, photooxygenation

\section{Introduction}

Dye-sensitized photooxygenation of olefins is carried out by irradiation with visible light of a solution prepared with an olefin and a sensitizer (methylene blue, eosin, tetraphenylporphyrin, etc.) and flushed with air or pure oxygen. ${ }^{1,2}$ The formation of singlet oxygen molecules $\left({ }^{1} \mathrm{O}_{2}\right)$ involves the excitation of a sensitizer molecule by a photon to singlet state; then the sensitizer relaxes to a triplet state by intersystem crossing and the energy is quenched by molecular oxygen resulting in excited singlet molecular oxygen. ${ }^{3}$

The attack of singlet molecular oxygen to an olefine carbon atom, with abstraction of an allylic hydrogen, yield an allylic hydroperoxide with migration of the double bond. In conformationally rigid cyclic six-membered olefins, the quasi-axial $\mathrm{C}$ - $\mathrm{H}$ bond is preferentially cleaved and a quasi- axial $\mathrm{C}-\mathrm{O}$ bond is created. Therefore, this is

* e-mail: fguare@ufba.br a stereosselective reaction ${ }^{4-6}$ and in suitable systems it may be used for the determination of allylic carbon stereochemistry.

The nature of the mechanism of the photooxygenation reaction is controversial. Several mechanistic approaches were proposed but only two, ene-like and peroxirane mechanisms are consistent with most experimental facts. Ene-like mechanism is a concerted 1,3 addition of ${ }^{1} \mathrm{O}_{2}$ to the olefin with formation of cyclic six-membered transition state. ${ }^{2}$ Nevertheless, azide quenching of intermediates in several photooxygenation reactions was not consistent with ene-like mechanism. In order to account for this fact, the mechanism that embraces a metastable peroxirane or perepoxide intermediate, which is analogous to the peracid olefin epoxidation, ${ }^{2}$ is preferentially accepted.

In this work, the stereosselectivity of olefins photooxygenation reactions was tentatively exploited for the establishment of the stereochemistry at C-8 in methyl entpimara-9(11),15-dien-19-oate, (1) (Figure 1). One of the expected products should be a compound with a 
hydroperoxide group at $\mathrm{C}-11$ on the same side of the molecule as H-8. The results obtained were not quite clear due to the formation of a complex mixture and low products yield, but stimulated us to study the photooxygenation reactions of isomeric compounds methyl ent-pimara-7,15-dien-19-oate,(2), and methyl entpimara-8,15-dien-19-oate, (3), (Figures 2 and 3).

\section{Experimental}

Melting points were determined on a Kofler apparatus and are uncorrected. The ${ }^{1} \mathrm{H}$ and ${ }^{13} \mathrm{C}$ NMR spectra of $\mathbf{5}$ to $\mathbf{8}$, were taken on a Bruker AC 200 and those of $\mathbf{9}$ and $\mathbf{1 0}$ were recorded on a Varian Gemini 300. EIMS: Direct probe insert at $70 \mathrm{eV}$ on a HP 5973 MSD. IR spectra of $\mathbf{6}$ and $\mathbf{8}$ were recorded on a Perkin-Elmer mod. 137 apparatus.

Pimaradienes $\mathbf{1}$ and $\mathbf{2}$ were obtained from the $n$-hexane extract of Mikania triangularis (Astereaceae) after methylation with $\mathrm{CH}_{2} \mathrm{~N}_{2}$. Compound $\mathbf{3}$ was obtained by acid isomerization of a mixture of $\mathbf{1}$ and $\mathbf{2} .^{7,8}$

Three different conditions of sensitizer/solvent were investigated, in a small scale, for the photooxygenation of

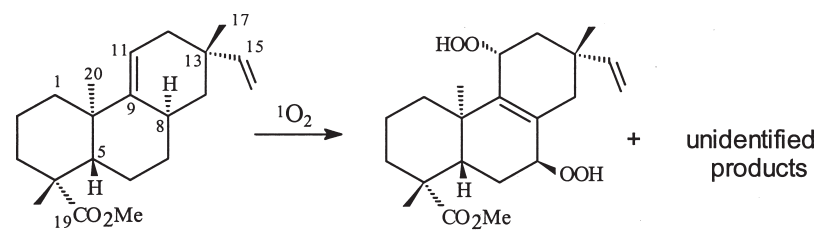

1

4<smiles>C=C[C@]1(C)CC2=C([C@@H]3CCCC(C)(C)[C@@]3(O)CC2O)[C@H](O)C1</smiles>

5

Figure 1. Photooxygenation of compound 1.

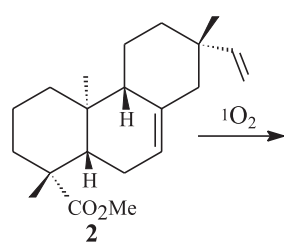

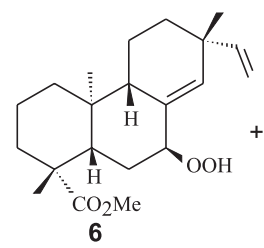

6

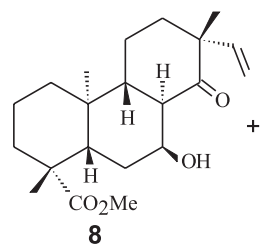

unidentified products<smiles>C=CC1C=C2C(O)CC3(CCCC)C(CCCC3(C)C)C2CC1</smiles>

Figure 2. Photooxygenation of compound 2.<smiles>C=CC1(C)CCC2=C(CCC3(C(C)=O)C2CCCC3(C)C)C1</smiles>

3<smiles>C=CC1(C)C=C2C(O)CC34C(CCCC3(C)C)CC2C4CC1</smiles>

$\downarrow$ KI<smiles>CC=CCCCC</smiles>

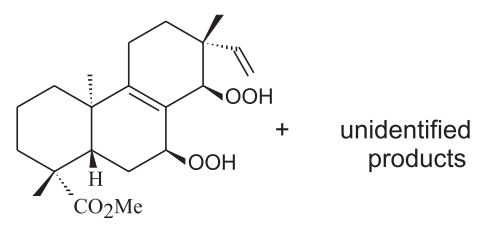<smiles>C=CC1(C)C=C2C(O)CC34C(CCCC3(C)C)C3CCCC(C)(C)C34CCC21</smiles>

9<smiles>C=CC1CCC2=C(C(O)CC3(C(C)(C)C)C(C)CCCC23)C1O</smiles>

Figure 3. Photooxygenation of compound 3. 
1: eosin/acetone, methylene blue/methanol and tetraphenylporphyrin (TPP)/carbon tetrachloride. The rate of conversion of $\mathbf{1}$ to the products was low in all cases, even after long periods of irradiation. Complex mixtures were obtained causing difficulties for the purification of products. The TPP/CCl system furnished better results in a preliminary evaluation by TLC and ${ }^{1} \mathrm{H}$ NMR and therefore it was chosen for the reaction.

Photosensitized oxygenation of compound 1. $\mathrm{A} \mathrm{CCl}_{4}$ $(100 \mathrm{~mL})$ solution of $1(623 \mathrm{mg}, 1.97 \mathrm{mmol})$ and TPP $(2 \mathrm{mg})$ was maintained at $5{ }^{\circ} \mathrm{C}$, flushed with $\mathrm{O}_{2}$ and irradiated with a Osram $500 \mathrm{~W}$ mercury lamp for $28 \mathrm{~h}$. After evaporation of the solvent, the residue was diluted in methanol $(50 \mathrm{~mL})$, then $\mathrm{KI}(2.0 \mathrm{~g})$ was added. The resulting solution was stirred for $1 \mathrm{~h}$ and allowed to stand for $16 \mathrm{~h}$. After evaporation of the solvent, the residue was dissolved in ethyl ether and washed with 5\% sodium thiosulfate solution and water, then the organic layer was dried with anhydrous sodium sulfate. The oil obtained after evaporation of the solvent $(610 \mathrm{mg})$ was chromatographed on silica gel $\mathrm{H}(30 \mathrm{~g})$ under $\mathrm{N}_{2}$ pressure. Elution with $n$-hexane/ethyl acetate gradient gave 1 (248 mg, 38\% recovered), and 5 (9 mg, 1.3\%) after recrystallization in methanol. The other fractions gave complex unidentified mixture.

Methyl-7 $\alpha, 11 \beta$-dihydroxypimara-8,15-dien-19-oate (5). Colorless solid, mp 219-220 $(\mathrm{MeOH})$. MS $\mathrm{m} / z$ (rel. int.): 348(0.5), 330(6), 315(4), 312(2), 289(1), 241(5), 237(8), 199(10), 197(10), 187(9), 185(13), 173(16), 171(17), 162(24), 161(21), 160(45), 159(23), 157(15), 147(35), 145(41), 131(31), 129(30), 119(43), 107(37), 105(66), 93(38), 91(76), 81(40), 79(60), 55(100), 41(77). ${ }^{1} \mathrm{H}$ and ${ }^{13} \mathrm{C}$ NMR: Tables 1 and 2.
Photosensitized oxygenation of compound 2. $\mathrm{A} \mathrm{CCl}_{4}$ $(100 \mathrm{~mL})$ solution of $2(330 \mathrm{mg}, 1.04 \mathrm{mmol})$ and TPP (2 $\mathrm{mg}$ ) was maintained at $5{ }^{\circ} \mathrm{C}$, flushed with $\mathrm{O}_{2}$ and irradiated, with a Osram $500 \mathrm{~W}$ mercury lamp until complete consumption of the starting olefin $(4 \mathrm{~h})$. The oil obtained after the evaporation of the solvent $(346 \mathrm{mg}$ ) was chromatographed on silica gel $\mathrm{H}(30 \mathrm{~g})$ under $\mathrm{N}_{2}$ pressure. Elution with $n$-hexane/ethyl acetate gradient furnished a fraction containing a mixture of compounds composed mainly of the hydroperoxide 6 ( $253 \mathrm{mg}$ ), and other fractions containing unidentified complex materials. The mixture containing 6 was rechromatographed on silica gel $(20 \mathrm{~g})$. Elution with $n$-hexane/ethyl acetate gradient gave $\mathbf{6}$ (122 $\mathrm{mg}, 34 \%$ ) and a fraction containing 8 with some impurity $(28 \mathrm{mg})$. Recrystallization of this fraction in methanol gave 8 (20 mg, 6\%).

Methyl-7 $\alpha$-hydroperoxypimara-8(14),15-dien-19 oate (6). Colorless oil. IR $v_{\max } / \mathrm{cm}^{-1}$ (film $\mathrm{CHCl}_{3}$ ): 3414,3080 , 2949, 2872, 1725, 1637, 1233, 1202, 1154, 988, 916. MS m/z (rel. int.): 348 (0.6), 331 (4), 330 (19), 289 (7), 271 (17), 270 (31), 162 (27), 149 (52), 148 (33), 147 (30), 133 (56), 119 (35), 107 (44), 105 (89), 93 (49), 91 (100). ${ }^{1} \mathrm{H}$ and ${ }^{13} \mathrm{C}$ NMR: Table 1 and 2.

Methyl-7 $\alpha$-hydroxy-14-oxopimara-15-en-19-oate (8). Colorless solid, mp 182-5 $(\mathrm{MeOH})$. IR $v_{\max } / \mathrm{cm}^{-1}$ (film $\mathrm{CHCl}_{3}$ ): 3547, 3097, 2993, 2971, 2907, 1710, 1645, 1250, 1218, 1203, 1150, 978, 927. MS $\mathrm{m} / \mathrm{z}$ (rel. int.): 348(2), 333(2), 330(2), 302(2), 301(2), 287(5), 273(5), 271(6), 255(5), 243(7), 227(5), 219(26), 211(56), 210(25), 179(31), 178(43), 152(11), 151(100), 150(12), 123(60), 121(19), 109(24), 107(60), 105(20), 95(46), 93(21), 91(19). ${ }^{1} \mathrm{H}$ and ${ }^{13} \mathrm{C}$ NMR: Table 1 and 2.

Table 1. Some characteristic ${ }^{1} \mathrm{H}$ NMR data for compounds $\mathbf{5}, \mathbf{6}, \mathbf{8}, \mathbf{9}$, and $10\left[\mathrm{CDCl}_{3}, d(\mathrm{ppm}), J(\mathrm{~Hz})\right]$

\begin{tabular}{|c|c|c|c|c|c|}
\hline $\mathrm{H}$ & 5 & 6 & 8 & 9 & 10 \\
\hline 7 & $4.39 \mathrm{~m}\left(\mathrm{~W}_{1 / 2}=8.6\right)$ & $4.38 \mathrm{~m}\left(\mathrm{~W}_{1 / 2}=7.1\right)$ & $4.05 \mathrm{~m}\left(\mathrm{~W}_{1 / 2}=8.5\right)$ & $4.35 \mathrm{~m}\left(\mathrm{~W}_{1 / 2}=8.3\right)$ & $4.07 \mathrm{~m}\left(\mathrm{~W}_{1 / 2}=3.8\right)$ \\
\hline 8 & & & $2.48 \mathrm{dd}(4.8 ; 16.7)$ & & \\
\hline 11 & $3.84 \mathrm{~m}\left(\mathrm{~W}_{1 / 2}=7.7\right)$ & & & & \\
\hline 14 & & $5.58 \mathrm{bs}$ & & $5.59 \mathrm{bs}$ & $4.21 \mathrm{~m}\left(\mathrm{~W}_{1 / 2}=7.7\right)$ \\
\hline 15 & $5.77 \mathrm{dd}(9.9 ; 17.2)$ & $5.70 \mathrm{dd}(10.0 ; 16.0)$ & $5.77 \mathrm{dd}(9.5 ; 16.6)$ & $5.66 \mathrm{dd}(10.3 ; 17.1)$ & $5.75 \mathrm{dd}(10.6 ; 17.4)$ \\
\hline $16 \mathrm{t}$ & 4.89 bd (17.2) & $4.85 \mathrm{dd}(1.6 ; 16.0)$ & 5.04 bd (16.6) & $4.82 \mathrm{dd}(1.4 ; 17.1)$ & $5.10 \mathrm{~d}(17.4)$ \\
\hline $16 \mathrm{c}$ & 4.87 bd (9.9) & $4.98 \mathrm{dd}(1.6 ; 10.0)$ & $5.11 \mathrm{bd}(9.5)$ & $4.95 \mathrm{dd}(1.4 ; 10.3)$ & $5.09 \mathrm{~d}(10.6)$ \\
\hline 17 & $1.21 \mathrm{~s}$ & $1.09 \mathrm{~s}$ & $0.97 \mathrm{~s}$ & $1.11 \mathrm{~s}$ & $1.00 \mathrm{~s}$ \\
\hline 18 & $1.21 \mathrm{~s}$ & $1.20 \mathrm{~s}$ & $1.15 \mathrm{~s}$ & $1.24 \mathrm{~s}$ & $1.22 \mathrm{~s}$ \\
\hline 20 & $0.74 \mathrm{~s}$ & $0.55 \mathrm{~s}$ & $0.76 \mathrm{~s}$ & $0.62 \mathrm{~s}$ & $0.74 \mathrm{~s}$ \\
\hline $\mathrm{OMe}$ & $3.63 \mathrm{~s}$ & $3.64 \mathrm{~s}$ & $3.64 \mathrm{~s}$ & & $3.63 \mathrm{~s}$ \\
\hline $\mathrm{OOH}$ & & $8.04 \mathrm{~s}$ & & & \\
\hline
\end{tabular}

Values in parentheses indicate coupling constants $J(\mathrm{~Hz}) ; \mathbf{5}, \mathbf{6}$ and $\mathbf{8}-200 \mathrm{MHz} ; \mathbf{9}$ and $10-300 \mathrm{MHz}$. 
Table 2. ${ }^{13} \mathrm{C}$ NMR data for compounds 5-11 $\left[\mathrm{CDCl}_{3}, \delta\right.$ (ppm)]

\begin{tabular}{lrrrrrrr}
\hline C & \multicolumn{1}{c}{$\mathbf{5}$} & \multicolumn{1}{c}{$\mathbf{c}$} & \multicolumn{1}{c}{$\mathbf{9}$} & \multicolumn{1}{c}{$\mathbf{1 0}$} & $\mathbf{7}^{\mathbf{7}}$ & $\mathbf{1 1}^{\mathbf{7}}$ \\
\hline 1 & 37.0 & 38.0 & 43.4 & 32.0 & 36.9 & 38.2 & 37.5 \\
2 & 19.4 & 18.7 & 20.3 & 19.2 & 20.0 & 18.7 & 19.4 \\
3 & 37.5 & 38.9 & 37.2 & 37.7 & 37.9 & 39.1 & 36.4 \\
4 & 43.6 & 43.8 & 44.6 & 43.9 & 44.1 & 43.9 & 43.5 \\
5 & 46.6 & 46.2 & 45.4 & 41.8 & 47.0 & 45.7 & 47.1 \\
6 & 29.9 & 27.2 & 26.9 & 31.2 & 29.7 & 30.8 & 30.2 \\
7 & 69.2 & 86.2 & 67.7 & 74.5 & 68.5 & 73.1 & 69.1 \\
8 & 131.7 & 134.4 & 67.4 & 138.2 & 128.5 & 140.3 & 126.5 \\
9 & 141.4 & 48.7 & 59.0 & 75.6 & 144.8 & 48.3 & 140.4 \\
10 & 39.2 & 38.7 & 38.9 & 42.6 & 39.7 & 38.4 & 38.7 \\
11 & 64.3 & 19.6 & 22.2 & 26.4 & 21.3 & 19.7 & 20.8 \\
12 & 41.5 & 35.4 & 32.2 & 31.4 & 32.3 & 35.5 & 33.5 \\
13 & 34.9 & 38.9 & 42.2 & 39.1 & 40.8 & 39.1 & 34.6 \\
14 & 42.7 & 137.5 & 214.3 & 136.5 & 77.9 & 133.0 & 39.8 \\
15 & 149.2 & 146.2 & 145.7 & 144.7 & 146.4 & 146.5 & 148.7 \\
16 & 109.7 & 113.5 & 112.6 & 113.2 & 113.6 & 113.0 & 109.9 \\
17 & 26.6 & 29.3 & 27.2 & 28.8 & 17.4 & 29.0 & 23.3 \\
18 & 28.3 & 28.6 & 28.7 & 28.9 & 28.7 & 28.6 & 28.2 \\
19 & 177.8 & 178.0 & 178.1 & 178.1 & 178.5 & 177.8 & 178.0 \\
20 & 17.3 & 12.9 & 17.0 & 16.3 & 16.7 & 12.8 & 16.0 \\
OMe & 51.3 & 51.3 & 51.3 & 51.3 & 51.7 & 51.0 & 51.2 \\
\hline 56 & & & &
\end{tabular}

5, 6 and $\mathbf{8}-50 \mathrm{MHz} ; \mathbf{9}$ and $\mathbf{1 0}-75 \mathrm{MHz}$.

Photosensitized oxygenation of compound 3. $\mathrm{A} \mathrm{CCl}_{4}$ $(150 \mathrm{~mL})$ solution of $\mathbf{3}(659 \mathrm{mg}, 2.09 \mathrm{mmol})$ and TPP (2 $\mathrm{mg}$ ) was maintained at $5{ }^{\circ} \mathrm{C}$, flushed with $\mathrm{O}_{2}$ and irradiated with a Phillips $250 \mathrm{~W}$ mercury lamp until complete consumption of the starting olefin $(8 \mathrm{~h})$. After evaporation of the solvent, the residue was diluted in methanol (50 $\mathrm{mL})$, then $\mathrm{KI}(2.0 \mathrm{~g})$ was added. The resulting solution was stirred for $1 \mathrm{~h}$ and allowed to stand for $16 \mathrm{~h}$. After evaporation of solvent the residue was dissolved in ethyl ether, washed with $5 \%$ sodium thiosulfate solution and water, and then dried with anhydrous sodium sulfate. The oil obtained after the evaporation of solvent was chromatographed on silica gel $\mathrm{H}(30 \mathrm{~g})$ under $\mathrm{N}_{2}$ pressure. Elution with benzene/acetone gradient gave $\mathbf{9}$ ( $23 \mathrm{mg}$, $3.3 \%)$ and $\mathbf{1 0}(29 \mathrm{mg}, 3.8 \%)$, after recrystallization in $n$ hexane/ethyl acetate.

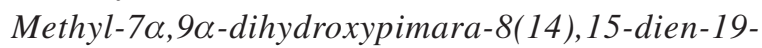
oate (9). Colorless solid, mp 204-5 (Hex/AcOEt): MS m/z (rel. int.): 348(1), 330(99), 312(27), 237(57), 163(100), 123(23), 109(52). ${ }^{1} \mathrm{H}$ and ${ }^{13} \mathrm{C}$ NMR: Tables 1 and 2.

Methyl-7 $\alpha, 14 \alpha$-dihydroxypimara-8,15-dien-19-oate (10). Amorphous colorless solid. MS $\mathrm{m} / \mathrm{z}$ (rel. int.): 330 [M- $\left.\mathrm{H}_{2} \mathrm{O}\right]$ (26), 301 (8), 262 (53), 247 (96), 202 (41), 187 (100), 159 (43), 133 (38), 105 (29). ${ }^{1} \mathrm{H}$ and ${ }^{13} \mathrm{C}$ NMR: Tables 1 and 2 .

Reduction of $\mathbf{6}$ with sodium borohydride. The solution of 6 (120 mg, $0.344 \mathrm{mmol}$ ), sodium borohydride (20 mg,
$0.526 \mathrm{mmol})$ in methanol $(10 \mathrm{~mL})$ was stirred for $30 \mathrm{~min}$ at room temperature. After the usual treatment and evaporation of solvent, the residue was chromatographed on silica gel $(5 \mathrm{~g})$ with $n$-hexane/ethyl acetate 8:2 and gave $7(112 \mathrm{mg}$, $98 \%)$.

All spectroscopic data of $\mathbf{7}$ were in good agreement with those reported previously. ${ }^{7}$

\section{Results and Discussion}

Compounds 5, 6, 8, 9, and $\mathbf{1 0}$ (Figures 1, 2 and 3) are new and their structures were determined by, ${ }^{1} \mathrm{H}$ and ${ }^{13} \mathrm{C}$ NMR, EIMS, and IR spectroscopy. Assignment of the ${ }^{13} \mathrm{C}$ NMR data (Table 2) of these compounds were made by comparison with data reported for $\mathbf{7}$ and for its $\Delta^{8}$ isomer 11, which were isolated from M. triangularis ${ }^{7}$ and other data reported in the literature. ${ }^{9}$ The positions of the double bonds and of the oxygenated carbons in these compounds became evident after comparison of their ${ }^{13} \mathrm{C}$ NMR spectral data with those of $\mathbf{7}$ and $\mathbf{1 1 .}$

The photooxygenation of $\mathbf{1}$ using TPP/CCl${ }_{4}$ system was carried out leading to $62 \%$ of conversion. The mixture was treated with a KI solution to reduce the hydroperoxides, yielding $5(1.3 \%)$ and other unidentified products.

In $\mathbf{5}$, the $\alpha$-quasi-axial ${ }^{10}$ hydroxyl group at $\mathrm{C}$-7 was established on the basis of ${ }^{13} \mathrm{C}$ NMR data, due the $\gamma$-gauche shielding effect that was observed at C-5 in comparison with $\mathbf{3}^{7}(\Delta \delta=-7,2 \mathrm{ppm})$. The agreement of the chemical shifts assignment for carbons 1 to 7 of $\mathbf{5}$ with those of $\mathbf{1 1}$, suggested the same structural arrangements for rings $A$ and $\mathrm{B}$ in both compounds. The $\Delta \delta=5.2 \mathrm{ppm}$ deshielding of C$8^{11}$ and $\Delta \delta=8.0 \mathrm{ppm}$ deshielding of $\mathrm{C}-12$, when compared with $\mathbf{1 1}$ located the second hydroxyl of $\mathbf{5}$ at C-11 $(\delta$ 64.3). The NMR spectral data of $\mathbf{5}$ are not sufficient to define $\mathrm{C}$ 11 stereochemistry, mainly because of ring $\mathrm{C}$ conformational flexibility. This compound was rather unstable and decomposed in a few days, it was, therefore, impossible to run other NMR experiments and its IR spectrum. Nevertheless, because of the well established stereosselectivity of the "ene-like" reaction, it's reasonable to attribute to the $\mathrm{C}$-11 hydroxyl a $\beta$-quasi-axial orientation.

The photooxygenation of $\mathbf{2}$ occurred with complete conversion producing $6(34 \%)$, the primary product of the reaction, and $\mathbf{8}$, an unexpected product. Compound $\mathbf{6}$ was then reduced with $\mathrm{NaBH}_{4}$ yielding 7 , which was identical to a natural product isolated from $M$. triangularis. $^{7}$

Compounds 6 and $7^{7}$ exhibited very similar ${ }^{1} \mathrm{H}$ and ${ }^{13} \mathrm{C}$ NMR spectra. The ${ }^{1} \mathrm{H}$ NMR spectra of these compounds showed only small differences due the presence of the hydroperoxide hydrogen signal at $\delta 8.04$ in $\mathbf{6}$ and the deshielding of H-14 of 6 in comparison with H-14 of 7. 
The ${ }^{13} \mathrm{C}$ NMR data of these compounds were similar and showed differences only at the double bond carbons $\mathrm{C}-8$ and C-14 and at C-7 (Table 2).

The ${ }^{1} \mathrm{H}$ NMR spectrum (Table 1 ) of compound $\mathbf{8}$ showed a dd at $\delta 2.48$. The coupling constants of 16.7 and $4.8 \mathrm{~Hz}$, suggest, respectively, an axial-axial and an axial-equatorial coupling. This signal was assigned to $\mathrm{H}-8$ through double irradiation experiments which demonstrated its vicinity with the carbinolic hydrogen $\mathrm{H}-7$ ( $\delta$ 4.05). The value of $\mathrm{W}_{1 / 2}$ to $\mathrm{H}-7(8.5 \mathrm{~Hz})$ suggests the axial orientation of hydroxyl group at C-7. The ${ }^{13} \mathrm{C}$ NMR spectral data (Table 2) showed the presence of a carbonyl group at $\delta 214.3$ (C-14), two methine carbons at $\delta 67.4$ (C-8) and $\delta 67.7$ (C-7) and the lack of an endocyclic double bond. The possibility of the $\mathrm{OH}$ group be located at $\mathrm{C}-14$ and the carbonyl at C-7 was abandoned since in this situation the carbinolic hydrogen would appear as a doublet.

The fotooxygenation of $\mathbf{3}$ also occurred with complete conversion of the starting material producing $9(3.3 \%)$ and $10(3.8 \%)$. In 9, the location of the hydroxyl group at C-9 $\left(\delta\right.$ 75.6) was suggested by the ${ }^{13} \mathrm{C}$ NMR spectrum analysis due to a deshielding effect observed for C-10, C-11 and $\mathrm{C}-14$, in comparison with 7 . The $\alpha$-orientation of the hydroxyl group was established by the shielding effect observed for C-1, C-5 and C-12, in comparison with those of 7 , due to $\gamma$-gauche interaction.

In 10, as in 5, the agreement of the ${ }^{13} \mathrm{C}$ NMR chemical shifts of the carbons 1 to 7 in comparison with $\mathbf{1 1}$, suggested the same structural arrangements of the A and B rings. The second hydroxyl group at $\mathrm{C}-14$ was suggested through the observation of deshielding effect at C-13 (+5.9 ppm) and C-9 (+3.4 ppm) and the $\gamma$-gauche effect observed at C-17 methyl group (-5.9 ppm). The molecular model shows that the more stable conformation occur with the $\mathrm{C}$ 14 hydroxyl in equatorial orientation, avoiding a 1,3diaxial interaction with $\mathrm{C}-7$ hydroxyl. The absence of pronounced $\gamma$-gauche effect at $\mathrm{C}-12$ could be explained by the fact that the $\mathrm{H}_{\alpha}-12$ was also equatorial.

From the three experiments only compound $\mathbf{2}$ gave the primary product of photoooxygenation. The formation of others products may be tentatively explained by the occurrence of a second photooxygenation reaction, ${ }^{12}$ followed by an allylic rearrangement of the hydroperoxide, ${ }^{13}$ probably induced by steric hindrance due to the introduction of a hydroperoxyl group in a congested side of molecule.

The low reactivity of $\mathbf{1}$ in comparison with $\mathbf{2}$ and $\mathbf{3}$ indicated a major steric hindrance on the $\Delta^{9,11}$ double bond. The same conclusion was reached with the epoxidation of these compounds with $m$-chloroperbenzoic acid..$^{7,8}$

\section{Acknowledgments}

The authors are grateful to PIBIC/UFBA for a fellowship to $\mathrm{M}$. D. de C. This work was supported by grants from CNPq and FINEP.

\section{References}

1. Kearns, D. R.; Chem. Rev. 1971, 71, 395.

2. Frimer, A. A.; Chem. Rev. 1979, 79, 359.

3. Schenck, G. O.; Ann. New York Acad. Sci. 1970, 171, 67.

4. Nickon, A.; DiGiorgio, J. B.; Daniels, P. J. L.; J. Org. Chem. 1973, 38, 533

5. Orfanopoulos, M.; Grdina, S. M. B.; Stephenson, L. M.; J. Am. Chem. Soc. 1979, 101, 275

6. Schulte-Elte, K. H.; Rautenstrauch, V.; J. Am. Chem. Soc. 1980, 102, 1738 .

7. Cruz, F. G.; Roque, N. F.; Phytochemistry 1992, 31, 2793.

8. Cruz, F. G.; Roque, N. F.; Quim. Nova 1997, 20, 261.

9. Pinto, A. C.; Figueiredo, M. R.; Epifanio, R. de A.; Phytochemistry 1992, 31, 1681.

10. The $\beta$-face of molecule was defined by the position of $\mathrm{C}-10$ methyl group, as in steroids nomenclature.

11. Delmond, B.; Taran, M.; Valade, J.; Petraude, M.; Barbe, B.; Org. Magn. Reson., 1981, 17, 207.

12. Gollnick, K.; Adv. Photochem. 1968, 6, 1.

13. Brill, W. F.; J. Am. Chem. Soc. 1965, 87, 3286.

Received: March 9, 2001

Published on the web: April 7, 2003 